\title{
Students' communicative competence in the context of intercultural business communication
}

\author{
Irina I. Klimova - Galina V. Klimova - Svetlana A. Dubinka
}

DOI: $10.18355 /$ XL.2019.12.01.16

\begin{abstract}
This paper considers the importance of improving students' sensitivity to culture, cultivating cultural awareness in the foreign language learning environment in order to develop the students' communicative competence. The authors analyze the inside constituents of the concept of culture. The influence of these components on verbal and communicative behavior of representatives of different cultures is reviewed. The purpose of this research paper was to implement our findings concerning fundamental components of the concepts of communicative competence and intercultural communication into a new course «Intercultural Business Communication» targeted at improving students' sensitivity to culture, cultivating cultural awareness in the foreign language learning environment.
\end{abstract}

Key words: communicative competence, intercultural communication, verbal communicative behavior, cultural differences, cultural barrier

\section{Introduction}

Considering the prospects for the development of the global economy and the sociocultural integration, the pedagogical purpose is developing university graduates' new professional and personal qualities such as: systemic, independent, creative thinking, ecological, sociocultural, linguistic and communicative competences, ability to conscious analysis of the specifics of their own professional activities, independent actions under conditions of uncertainty and variability of the world. Due to the current conditions, more attention in the process of teaching students in higher education institutions should be paid to mastering language for specific purposes, focused on students' professional linguistic needs, fluency in a foreign language as a necessary means of intercultural communication in the educational, everyday, scientific and professional spheres of life.

As international business partnerships become more common across the globe, formation, and development of communicative competence become necessary to facilitate effective cross-cultural business communication. New realities pose strong challenges for higher education. It is necessary to change the approach to the choice of teaching methods, the content of the courses to meet the requirements. The main goal of the educational process is the development of communicative competence, which, in addition to linguistic competence, includes mastering the practical skills of cross-cultural communication. The study of models of adequate sociocultural behavior in various communicative situations should be a matter of priority. Successful verbal communication implies appropriate usage and proper combination of various linguistic units in speech. When combining words from different languages, we essentially combine the worlds of the native speakers and their language-based world view. That is why the setting of appropriate context for crosscultural communication as well as the development of sociocultural and communication skills along with the language skills are among the integral components of cross-cultural communicative competence. Knowledge of vocabulary of advanced level and efficient use of grammar rules are not enough to actively use the language as a means of communication. It is necessary to make a student be immersed into the world of the studied language. Besides lexical knowledge and

XLinguae, Volume 12 Issue 1, January 2019, ISSN 1337-8384, eISSN 2453-711X 
knowledge of grammar rules, one must have an ability to freely navigate in a foreign language environment and react adequately in various communication situations, i.e. interlocutors should not only know how to communicate with sensitivity but also how to behave themselves in the different cultural environment, applying language skills to practice.

The object of the study is the process of developing students' communicative competence through intercultural business communication in higher educational institutions in the course of their study of a foreign language.

The subject of the study is a means of the formation and development of communicative competence including an ability that ensures the effectiveness of intercultural business communication in the studied language.

The purpose of the study is the theoretical underpinning of the mechanisms of cultural reflection in language and speech, the structure of communicative competence, the principles of its formation in the process of learning a foreign language, the content of the learning process and the system of tasks aimed at the formation of communicative competence by means of cross-cultural business communication.

The tasks of the study are as follows:

- to justify a set of concepts that constitute the theoretical and methodological background for the study of the reflection of the culture in language and speech, in the behavior of native and non-native speakers

- to develop, theoretically substantiate and experimentally confirm the principles of the formation of communicative competence in the process of learning a foreign language in a higher educational institution

- to determine the training content, design a course aimed at the formation of communicative competence through cross-cultural communication and test it in the experiment.

\section{Literature review}

\subsection{Communicative competence through intercultural communication}

The communicative approach to language teaching begins with a theory of language as communication. Developing communicative competence is the main objective of language teaching. The first investigations into linguistic competence was performed by Chomsky (1965), who claimed that linguistic theory is concerned primarily with an ideal speaker-listener in completely homogeneous speech community, who knows its language perfectly and is unaffected by such grammatically irrelevant conditions as memory limitation, distractions, shifts of attention and interest, and errors (random or characteristic) in applying his knowledge of the language in actual performance. However, Hymes (1972) coined the term «communicative competence» in order to mismatch Chomsky's theory of competence and a communicative view of language.

For Chomsky, the linguistic theory was focused on describing the linguistic competence that enables speakers to produce grammatically correct sentences in a language. According to Hymes, such a view of linguistic theory was pointless, as it failed to be seen as part of a more general theory embodying communication and culture in order to demonstrate all the aspects of language. Hymes's studies tended to focus on the need of the theory that incorporated communicative competence, which was a definition of what a speaker needs to know in order to be communicatively competent in a speech community. In the scientist's view, developing communicative competence meant acquiring both knowledge and ability for language use with respect to:

- $\quad$ whether (and to what degree) something is formally possible

- $\quad$ whether (and to what degree) something is feasible in virtue of the means of implementation available

- $\quad$ whether (and to what degree) something is appropriate (adequate, happy, successful) in relation to a context in which it is used and evaluated 
whether (and to what degree) something is in fact done, actually performed, and what its doing entails (Hymes, 1972:281).

But, Hymes "did not pay specific attention to cross-cultural communication, he was concerned to analyze social interaction and communication within a social group using one language" (Byram, 1997:9).

In the same vein, Canal and Swain (1980) proposed four dimensions of communicative competence:

- $\quad$ linguistic competence (ability to use language accurately)

- $\quad$ sociolinguistic competence (ability to produce sociolinguistically appropriate utterances)

- discourse competence (ability to produce a text that is connected and coherent)

- $\quad$ strategic competence (ability to use language functionally and strategically, which helps to solve communication problems as they arise).

Within this framework, communicative competence, like the other aspects of communication and culture, is a wider concept, which differs across cultures as a result of different levels of expected participation, various types of values and beliefs, various kinds of knowledge, various social situations, various ethnical principles, and standards.

In view of the above said, communicative competence in the context of intercultural communication involves not only communicative competence in linguistic and pragmatic terms of the language used in the intercultural encounter, more importantly, it requires the ability to go between different cultural identities and awareness of different sets of cultural scripts or patterns of interaction which are unique to a particular culture.

So students' communicative competence in the context of intercultural communication or intercultural communication competence can be defined as their ability to take part in productive intercultural dialogues of meanings and relationships with people from different cultures. Successful intercultural interaction requires the person to be able to build rapport with people from different cultural backgrounds through appropriate and effective use of verbal and nonverbal language (Song, 2009).

Currently, interaction with people from different cultures by means of communication and establishing contacts is an essential way to learn more about other people and their way of life, including their values, habits, customs, traditions, history and their personality. As humans, all people have the same necessities and desires, but different ways of achieving them. When studying all these, students learn how to develop a tolerance for difference. This can be accomplished only when they build relationships with people who are different from themselves during their professional life. Therefore, the goal of English language teaching should be to improve students' communication skills ( $\mathrm{Li}$ et al., 2017) which include not only linguistic competence but also intercultural competence which promotes and facilitates communication across cultures. Clearly, knowledge of intercultural communication can help solve communication problems before they arise.

Increased contacts with other cultures in the contemporary world is a primary target for educators to teach students to understand and get along with people who may be vastly different from us. The increased awareness and understanding of other culture and people who may not share our views beliefs, values, customs, habits, and lifestyles will eventually enhance our ability to coexist peacefully with people of other cultural backgrounds and to help resolve international conflicts (Samovar, Porter, Stefani, 2000).

Multiple studies by Russian-speaking and international authors (Visson, 2001; Lakoff, Johnson, 2003; Lewis, 2008; Kamalova, Zakirova, 2014; Menter, 2017; Khrulyova,

XLinguae, Volume 12 Issue 1, January 2019, ISSN 1337-8384, eISSN 2453-711X 
Sakhieva, 2017; Dorozhkin et al., 2018) are dedicated to the deconstruction of cultural differences and forecasting the characteristics of doing business with representatives of other countries.

\subsection{Culture: Characteristics and Classifications}

Learning foreign languages plays a crucial role in intercultural business communication studies. But equally important is developing communicative competence in the context of intercultural communication, that is, a recognition of the cultural factors influencing behavior in business encounters around the globe (Beamer, 1992; Bennett, 1986; Varner, 2001).

There is not only a language barrier between people of different countries but, what is no less important, also a cultural barrier. While language mistakes are forgiven to foreigners, cultural mistakes are not forgiven to anybody (including foreigners), and they can lead to cultural and ethnic conflicts (Ter-Minasova, 2008: 94).

Culture is something that lies deeper than etiquette or the way we introduce a business partner or hand our business card. Culture lies at the core of communication and concepts of the native speaker. Those concepts include values, views, and religious beliefs, treatment of such important categories as time, punctuality, social status, truth, sincerity, as well as laws that regulate our interaction with other members of society and are reflected in the language as an important component of verbal communicative behavior.

Culture-dependent values differ in a ratio between achievement, career, and quality of life. For some cultures, the guiding principle can be expressed as "live to work", whereas for others it is the opposite - "work to live". Such a difference could explain numerous conflicts associated with a work ethic approach taken by representatives of different cultures.

Cultures can also be divided into two categories - the doing oriented cultures and being based on cultures. The main question here is which is more important to a particular culture: personal achievement or family status. For example, the English words "ambition" and "ambitious" have a positive connotation and are regarded as praise for personal success and active life position, whereas in Russian the words are typically used to give a negative evaluation. In English and American cultures, both of which are oriented towards a successful career, metaphors that imply career growth are common. Prime examples of this would be "He had a lofty position", "She will rise to the top", "He has little upward mobility", "He's at the bottom of the social hierarchy" or "She fell in status".

Beliefs, including religious beliefs, views, and life goals also belong to the fundamental concepts of culture. A concept of fate and the role of external circumstances divide cultures into the so-called high and low context cultures (Hall, Hall, 1983:73). In the former, which includes many eastern cultures, greater importance is assigned to external circumstances as well as to social and contextual factors, thus their style of communication is indirect, implicit, and allows for reading between the lines. In the latter, cultures such as that of Germany, USA or the UK, concepts, and ideas in both oral and written forms are expressed directly, explicitly and are well argued. Not knowing such an important difference between these two groups of culture may create problems in the course of business communication. High context cultures representatives may seem evasive and slippery to their partners and, thus, not be prepared for constructive negotiations (Baryshnikov, Vartanov, 2018). On the other hand, low-context culture representatives may appear aggressive and unrelenting concerning key questions, and, thus, not ready for negotiations. Awareness of culture-based behavior in other people can help overcome the cultural barrier and find a compromise.

Another vital differentiating criterion for the categorization of cultures is a concept of fate and the amount of control one has over his/her own life as well as the surrounding 
events. Controlling fate-changing circumstances, weather forecasting, and planning of the future are all characteristic of Western cultures. A common English phrase goes "I'm on top of the situation". Eastern cultures, including, for instance, Arabic ones, think they have only little control over their own fate living by the motto "it's going to be how it's going to be", which makes them regard the concept of punctuality less, thus appearing negligent with respect to the time of scheduled meetings. If in Western cultures, a man is the nature's king, in Eastern cultures it is important to live in harmony with nature.

Cognitive styles and ways of thinking can also be regarded as culture differentiation criteria. In the countries of North America and Northern Europe, inductive thinking prevails: people focus on facts and details, and then use this information to build general conclusions. In Latin American culture, there is a tendency towards deductive thinking: people begin with general principles and then use them to identify and analyze the details of each situation individually. This can lead to some complications in business communication and business meetings. For example, Americans will use details to structure business relationships. Their French counterparties, on the contrary, will first try to focus on the format, and then move on to the details of the transaction. The holistic approach is reflected in the difference of approaches people utilize to form an agenda for a business meeting. Meetings organized by French business partners are distinguished by the fast pace of conducting the meeting itself and a lengthy discussion that allows you to feel the reaction of your business colleagues and show your eloquence. The agenda, therefore, goes beyond the format of a meeting, but serves as an incentive for discussion and exchange of ideas, often in the form of philosophical reasoning. Important components in the discussion format for representatives of cultures with a rigid attitude to the agenda are argumentation, persuasion, determination, and upholding of their position. An example of this is the following metaphorical statements that oppose the concepts of "rational" and "emotional": "The discussion fell to the emotional level, but I raised it back to the rational plane ', 'We put our feelings aside and had a high-level intellectual discussion of the matter', 'He couldn't rise above his emotions' or 'Try to pack more thoughts into fewer words'.

An important sociocultural factor influencing verbal communicative behavior is individualism vs collectivism (Ter-Minasova, 2008:54). In verbal communication among representatives of English and American cultures, this difference is expressed in a number of lexical, grammatical and stylistic techniques. The grammatical category of the article in English (and some other languages) emphasizes the selectivity of the subject, which must be either singled out from a group or unique in its own way. Writing the first-person singular pronoun ' $I$ ' with a capital letter in English emphasizes the individuality and responsibility of the speaker, which corresponds to the individualistic approach in a given culture. In Russian, the formal pronoun of the second person singular 'You' is written with a capital letter. Whereas the English language does not differentiate a formal and informal address to a person through a different spelling of the second person singular pronoun. In Russian scientific and official business writing, it is customary to write about arguments and conclusions in the form of the first person plural or impersonal form: we suggest, I think, it is believed, we found... An author writing in English will relate the same content without any false modesty or pretending to be too open, by using the first person singular: "I propose, I believe, we found out ..."

The attitude to time is an extremely important parameter of cultural differences in business communication. Punctuality, scheduling business meetings, deadlines, etc. are all perceived through the lens of conceptual understanding of time.

In English, the treatment of time is expressed through the concepts of 'Time is money', 'Time is a resource' or 'Time is a valuable commodity' This special relation

XLinguae, Volume 12 Issue 1, January 2019, ISSN 1337-8384, eISSN 2453-711X 
to time is reflected in a number of metaphorical expressions: 'I don't have time to give you', 'That flat tire cost me an hour', "He lives on time borrowed", 'to make time', 'to sell time' etc.

We emphasize that the classification of cultures according to one principle or another reflects only the tendencies cultures have, and it is sometimes difficult to draw a clear line between cultures. However, it is important to stress that there are no bad or good trends in the manifestation of cultural differences. It is also essential to note that any scientific classification of this kind is necessary as a guidebook that must be handled with care, considering each case of verbal communication and each representative of the culture individually. Behavioral characteristics may be inherent to representatives of different cultures as personal qualities. Therefore, assessments of these behavioral characteristics must be made by different rules, using an individual approach, as opposed to the perspective of another culture.

The study of the deep components of culture is very important for the classification of cultures, both in theoretical and practical terms. Knowledge of linguistic features that are socio-cultural in nature is necessary for two reasons. It is very important for overcoming the language barrier, understanding and sensing the subtleties of a language, which are caused not only by grammatical, lexical and stylistic features and rules. Knowledge of cultural and linguistic difficulties is also necessary to overcome the cultural barrier. Therefore, language learning today should include overcoming the cultural-language barrier, as verbal communication and verbal communicative behavior are conditioned on a sociocultural perspective. University level foreign language courses should pay attention not only to the traditional aspects of the language and types of speech activity but also to the study of intercultural differences in personal and business communication. The study of underlying components of culture is necessary for understanding the essence of the classification of cultures. This classification is important for determining expectations from our business partners in such serious issues as preparing meeting agenda, setting deadlines, scheduling a business meeting, treating punctuality, etc. The study of these cultural characteristics, which are projected onto verbal and non-verbal communicative behavior, contributes to a mutual understanding as well as prevention of failures in communication and cultural conflicts.

Thus a set of values, ideas, stereotypes, individual culture, and professional culture are expressed or implicitly manifested at different language levels and in speech. The modern methodology is aimed at studying the problem of developing a student's cultural literacy, forming a language policy strategy and teaching tactics for intercultural communication in a foreign language learning process.

\section{Research methodology}

Totally 100 students of different majors from the Financial University under the Government of the Russian Federation participated in the survey.

Various methods were used. Theoretical methods included the analysis of the scientific works on the issue of the study, the analysis of methodological and educational literature; the theoretical justification of the development of communication competence by means of cross-cultural communication. Empirical methods consisted of inclusive observation, pedagogical experiment formation, questioning, analyzing the results of experimental work.

The study was conducted in three stages in 2015-2018.

At the first stage (2015-2016) we analyzed the investigations of this issue by scientists, studied the scientific and methodological works, formulated the aim, subject, object and the main tasks of the study, revealed the state of the problem, and studied conditions of the pedagogical experiment. The second stage (2016-2017) was devoted to determining teachers' work content, designing teaching materials, testing their efficiency, preparation of the curricula and methodical guidelines for the 
teachers, asking students for the feedback, revealing some gaps in methodology, improving the content of the course and teaching materials. During the third stage (2017-2018) we carried out experiment implementing the course «Intercultural communication» into the educational process, documented the research, presented the results on the public at the international scientific conferences.

\section{Results and Discussion}

The purpose of this research paper was to implement our findings concerning fundamental components of the concepts of communicative competence and intercultural communication into a new course «Intercultural Business Communication» targeted at improving students' sensitivity to culture, cultivating cultural awareness in the foreign language learning environment. Table 1 shows the planned results for the course demonstrating the indicators of their planned learning outcomes.

Table 1: The list of planned results for the course demonstrating the indicators of their planned learning outcomes

\begin{tabular}{|c|c|c|}
\hline Code & Competence & $\begin{array}{l}\text { Learning outcomes (proficiency, skills, and knowledge) } \\
\text { related to competences/indicators of competence } \\
\text { achievement }\end{array}$ \\
\hline IC-6 & $\begin{array}{l}\text { Ability to } \\
\text { apply } \\
\text { knowledge of a } \\
\text { foreign } \\
\text { language at a } \\
\text { level sufficient } \\
\text { for } \\
\text { interpersonal } \\
\text { and } \\
\text { intercultural } \\
\text { communication } \\
\text { and learning } \\
\text { activities }\end{array}$ & $\begin{array}{l}\text { Students should know: } \\
\text { - the meanings of the studied lexical units in situations of } \\
\text { interpersonal and intercultural communication in the } \\
\text { areas of activity envisaged by different training programs } \\
\text { - grammatical phenomena and structures used in verbal } \\
\text { and written communication } \\
\text { - basic norms of social behavior and speech etiquette } \\
\text { adopted in English-speaking countries. } \\
\text { Students should be able to: } \\
\text { - use a foreign language in situations of interpersonal and } \\
\text { intercultural communication in educational and } \\
\text { professional activities } \\
\text { - report information on the basis of the given text in the } \\
\text { form of a prepared monologic utterance } \\
\text { - implement communicative intentions (to establish and } \\
\text { maintain contacts, to request and report information); } \\
\text { - understand the information when reading educational } \\
\text { and reference books in accordance with the specific } \\
\text { purpose } \\
\text { - implement communicative intentions in writing } \\
\text { (informing, proposing, requesting, prompting to action, } \\
\text { requesting, (not) consent, refusal, apology, gratitude) } \\
\text { - note down the information obtained when reading the } \\
\text { text, listening, watching the video. } \\
\text { Students should master: } \\
\text { - the methods of public speech and discourse in a foreign } \\
\text { language } \\
\text { - the basics of business communication and speech } \\
\text { etiquette of the target foreign language } \\
\text { - the ability to use competently and effectively foreign } \\
\text { sources of information } \\
\text { - writing skills in accordance with the communicative }\end{array}$ \\
\hline
\end{tabular}

XLinguae, Volume 12 Issue 1, January 2019, ISSN 1337-8384, eISSN 2453-711X 
The content of the course includes the following themes:

1. Culture is the key to competitiveness. Working across cultures. Communication with foreign partners. European and Asian communication styles.

2. Understanding cultural patterns. International Business. Cooperation with European companies. Doing business in China and India. The importance of understanding the specifics of the local culture.

3. Interculturality. The merger of international companies. The positive and negative experience of merges.

4. Culture and organization. Overseas assignment. Responsibility, difficulties, and prospects of working abroad.

5. Best practices. Working in an international team. International e-business and its specifics. Participation in international projects and programs.

Studying abroad. Skills for successful management careers.

The formative assessment of knowledge, skills, and competencies during the course (until the midterm) is carried out in the form of the following assessment activities:

- written homework performance

- lexical and grammar tests

- monological and dialogical practices

- individual or group presentations on a given topic

- project work

- tests created by means of a computer-aided testing system

The midterm assessment includes various types of assignments. The maximum score a student can get for the midterm work is ten scores.

Table 3: Midterm assessment

\begin{tabular}{|c|c|c|c|}
\hline \multicolumn{3}{|c|}{ Midterm work (01-10 November) } & \multirow[b]{2}{*}{$\begin{array}{l}\text { Total } \\
\text { score }\end{array}$} \\
\hline $\begin{array}{c}\text { Lexical and grammar } \\
\text { test } \\
\text { Paper-based } \\
\text { test/online test } \\
(40 \text { tasks })\end{array}$ & $\begin{array}{l}\text { Audio test } \\
(10 \text { tasks })\end{array}$ & $\begin{array}{c}\text { Individual / group } \\
\text { presentations / case-study }\end{array}$ & \\
\hline three scores & three scores & four scores & $\begin{array}{c}\text { ten } \\
\text { scores }\end{array}$ \\
\hline
\end{tabular}

The teachers, as well as students, prefer using online tests created utilizing the computer-aided testing system due to their interactivity, objectivity of the results, assessment of language knowledge, possibility to assess students' skills to differentiate cultures and understanding of basic rules of cross-cultural business communication.

Table 4: Online test samples

Choose the best phrase or word to complete the sentence.

1. Leaders in Asian countries put a lot of emphasis on maintaining group ... and avoiding open disagreement.

a) behavior c) misunderstandings

b) harmony d) decisions

2. Geert Hofstede chose IBM for his famous study on the effect of culture on organizations because IBM had a very strong ...
a) corporate culture
c) work ethic 


\begin{tabular}{|c|c|}
\hline \multirow{2}{*}{\multicolumn{2}{|c|}{$\begin{array}{l}\text { b) product range d) management style } \\
\text { 3. Large companies in Japan need to show a strong sense of ... because of their } \\
\text { important role in the community. }\end{array}$}} \\
\hline & \\
\hline a) customer loyalties & c) social awareness \\
\hline b) social responsibility & d) employee awareness \\
\hline \multicolumn{2}{|c|}{$\begin{array}{l}\text { 4. The decision-making process in Japan is based on ... consent-everyone must agree. } \\
\begin{array}{ll}\text { a) commendable } & \text { c) unanimous }\end{array}\end{array}$} \\
\hline b) meticulous & \\
\hline \multicolumn{2}{|c|}{$\begin{array}{l}\text { 5. When companies from two or more cultures come together, the leaders need to find } \\
\text { a way of working together in a ... way. }\end{array}$} \\
\hline a) communicative & \\
\hline b) collaborative & \\
\hline \multicolumn{2}{|c|}{$\begin{array}{l}\text { Guess the word from the definition. } \\
6 \text {. When we work with people from other cultures, we usually start off with ... of how } \\
\text { they will behave. }\end{array}$} \\
\hline a) beliefs & c) attitudes \\
\hline b) expectations & d) traditions \\
\hline 7. Ideas that you believe to be true & e, especially ones that form part of a system of ideas \\
\hline
\end{tabular}

To enhance students' cross-cultural awareness, we also offered distance-learning format in addition to the traditional on-campus program for our students. A special online course «Intercultural Business communication» was designed by the teachers of the Financial University under the government of the Russian Federation thanks to a well-constructed electronic learning environment provided by the University (informational, educational portal (http://online.fa.ru) which is available for the teachers and students of the university). The access to students for registration on the portal of the Open Online Academy of the Financial University (http://online.fa.ru) was open on the 1st of October, 2018 (from October 1 to November 1). Students were given the opportunity to enroll in online courses hosted on the portal.

\section{Figure 1: Online course content}

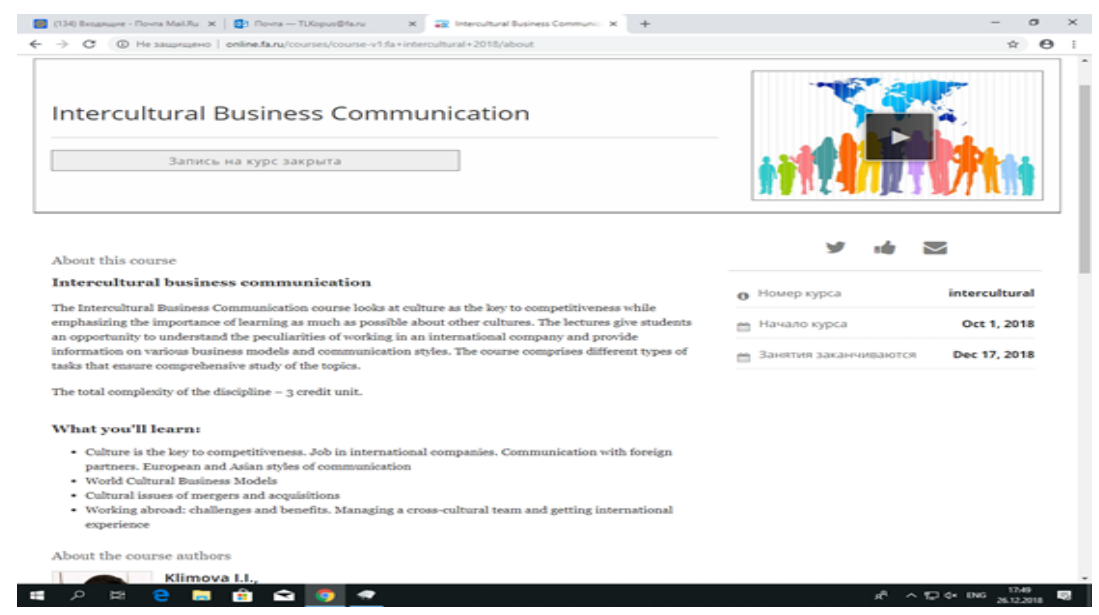

XLinguae, Volume 12 Issue 1, January 2019, ISSN 1337-8384, eISSN 2453-711X 
The online course comprised different types of tasks that insured a comprehensive study of the topics. The lectures were given by highly qualified lecturers, including native speakers.

\section{Figure 2: Online course content}

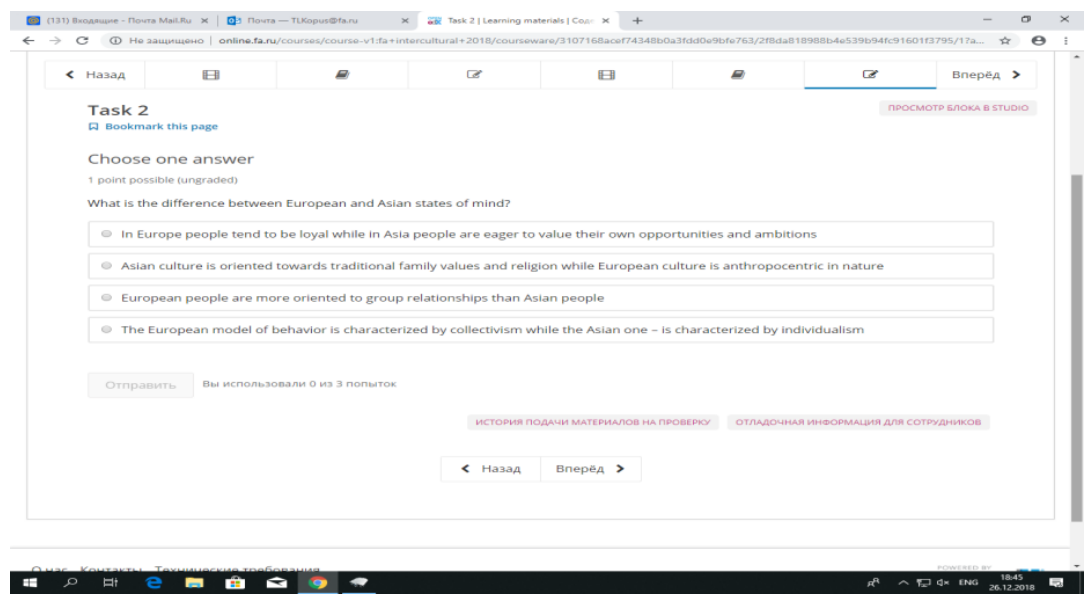

Students had an opportunity to choose the format of studying: an eLearning format or a traditional course. They were presented a variety of options: those who did not pass the final online course test were given a chance to do the paper-based test with students enrolled in a traditional course, within the time limits set for the discipline. The efficient balance of online and offline technologies used during the course prepared the students for an adequate perception of reality, helped to avoid the state of uncertainty, experienced by a person who first appeared in a real foreign environment.

\section{Conclusion}

Thus, there is a wide range of various forms and methods of the formation of students' communicative competence. The formation and development of students' communicative competence require strong collaboration between a teacher and students. The communicative language teaching of a modern specialist should become a mandatory component of higher education.

It is obvious that EFL teaching entails not only a set of grammar rules and vocabulary but also a set of social settings in which the language develops and behavior within a communicative group. Therefore, EFL teaching cultivates students' linguistic competence as well as communicative competence in the context of intercultural communication, English language teachers being aware of the relationship between linguistic competence and intercultural communication competence. In addition, the English language teachers should adopt some effective measures to cultivate the students' basic knowledge and skills of intercultural communication, enhance the students' intercultural communication awareness through various teaching modes, so as to realize the goal of English language teaching to cultivate the students' intercultural communication competence (Zhang, Zhang, 2015).

A specialist in any field can make a positive impression on anyone only in case he or she expresses thoughts and ideas correctly, explains things clearly, persuades insistently, effectively presents himself or herself. The course «Intercultural business communication» should be an integral part of the curricula not only for students of our university but also for other educational institutions. Knowledge of a foreign 
language, a culture of speech contributes to the formation of a competitive specialist in the labor market, which will significantly improve the status of higher education institutions and ensure its further development.

\section{Bibliographic references}

BARYSHNIKOV, N.V. - VARTANOV, A.V. 2018. Ten 'Whys' about intercultural communication. In: Advances in Intelligent Systems and Computing, n. 677, pp. 219230. ISSN: 2194-5357.

BEAMER, L. 1992. Learning intercultural competence. In: Journal of Business Communication, vol. 29, n.3, pp. 285-303. ISSN: 2329-4884.

BENNETT, M. J. 1986. A developmental approach to training for intercultural sensitivity. In: International Journal of Intercultural Relations, n. 10, pp. 179-195. ISSN: 0147- 1767.

BYRAM, M. 1997. Teaching and Assessing Intercultural Communicative Competence (1st ed.). Clevedon: Multilingual Matters. 136 p. ISBN-13: 9781853593772.

CANALE, M. - SWAIN, M. 1980. Theoretical bases of communicative approaches to second language teaching and testing. In: Applied Linguistics, vol. 1, n. 1, pp. 1-47. ISSN: 0142-6001.

CHOMSKY, N. 1965. Aspects of the Theory of Syntax. Cambridge Mass: MIT Press. DOROZHKIN, E.M. - KALIMULLIN, A.M. - MIGACHEVA, G.N. - SOKOLOVA, T.B. 2018. Optimization of the Subject Matter of Profile Training Disciplines for Bachelors' Vocational Education on the Basis of Occupational Standards. In: EURASIA Journal of Mathematics, Science and Technology Education, vol. 14, n. 3, pp. 859-876. ISSN: 13058215, 13058223.

HALL, E.T. - HALL, M.R. 1983. Understanding Cultural Differences: Germans, French, Americans. Yarmouth, ME: Intercultural Press. 180p. ISBN-10: 1877864072. HOFSTEDE, G. 1991. Cultures and Organizations: Software of the Mind, Intercultural Cooperation and Its Importance for Survival. Maiden head McGraw-Hill. 200p. ISBN: 978-0-07-166418-9.

HYMES, D. 1972. "Competence and Performance in Linguistic Theory", in R. Huxley \& E. Ingram (eds.) Language Acquisition: Models Bed Methods. New York: Academic Press, pp.3-23.

KAMALOVA, L.A. - ZAKIROVA, V.G. 2014. Technique of comparative studying of the Russian and Tatar national fairy tales at modern elementary school in a context of dialogue of cultures. In: Middle - East Journal of Scientific Research, vol. 2, n. 1, pp. 33-37. ISSN: 19909233, 19998147.

LAKOFF, G. - JOHNSON, M. 2003. Metaphors we live by. Chicago and London: University of Chicago Press. 276p. ISBN: 0-226-46801-1.

LEWIS, R.D. 2008. When Cultures Collide: Leading Across Cultures. $3^{\text {rd }}$ ed. Boston, London. 600p. ISBN-13: 978-1-904838-02-9.

LI, N. - PYRKOVA, K.V. - RYABOVA, T.V. 2017. Teaching Communication Skills and Decision-Making to University Students. In: EURASIA Journal of Mathematics, Science and Technology Education, vol. 13, n. 8, pp. 4715-4723. ISSN: 13058215 ,

13058223.

KHRULYOVA A.A. - SAKHIEVA R.G. 2017. Forming of Informational Culture as

a Necessary Condition of the Level Raising of Higher Education. In: Man In India, vol. 97, n. 15, pp. 211-225. ISSN: 00251569.

MENTER, I. - VALEEVA, R. - KALIMULLIN, A. 2017. A tale of two countriesforty years on: politics and teacher education in Russia and England. In: European Journal of Teacher Education, vol. 40, n. 5, pp. 616-629. ISSN: 14695928, 02619768.

XLinguae, Volume 12 Issue 1, January 2019, ISSN 1337-8384, eISSN 2453-711X 
SAMOVAR, L.A. - PORTER, R.E. - STEFANI, L.A. 2000. Communication Between Cultures. Beijing: Foreign Language Teaching and Research Press, pp. 66$69 ; 79-81$.

SONG, L. 2009. Teaching English as Intercultural Education Challenges of Intercultural Communication. In: Journal of Intercultural Communication Research, vol. 1, pp. 268. ISSN: 1747-5759.

TER-MINASOVA, S. G. 2008. War and peace of languages and cultures. Moscow, Slovo. 342 p. ISBN: 5-211-00772- 7.

VARNER, I. 2001. Teaching intercultural management communication: Where are we? Where do we go? In: Business Communication Quarterly, n. 64, pp. 99-111. ISSN: $1080-5699$.

VISSON, L. 2001. Synchronous translation from Russian to English. Moscow, R. Valent. 200 p. ISBN: 5-ЧЭЧЗЧ-077-5.

ZHANG, X. - ZHANG, J. 2015. English Language Teaching and Intercultural Communication Competence. In: International Journal for Innovation Education and Research, vol. 3, n. 8, pp. 55-59. ISSN: 2411-3123.

Words: 5412

Characters: 37778 (20,99 standard pages)

Prof. Irina I. Klimova

Department of Foreign Languages

Financial University under the Government of the Russian Federation

Leningradsky prospect 49

125993 Moscow

Russia

iiklimova@mail.ru

Lecturer Galina V. Klimova

KPMG Department

Financial University under the Government of the Russian Federation

Leningradsky prospect 49

125993 Moscow

Russia

gale.klimova@gmail.com

Prof. Svetlana A. Dubinka, PhD

Department of English for Economics

Belarusian State University

4, Nezavisimosti avenue

220030 Minsk

Republic of Belarus

svetlanadubinko@gmail.com 